\title{
Protonation of meso-Tetraphenylporphyrin and Its $\beta$-Functionalized Derivatives by Photogenerators of Acidity in Toluene and Polymer Film
}

\author{
Valerii F. Traven, ${ }^{\mathrm{a} @ 1}$ Nuno M. M. Moura, ${ }^{\mathrm{b} @ 2}$ Svetlana B. Scachkova, ${ }^{\mathrm{a}}$ \\ M. Amparo F. Faustino, ${ }^{\mathrm{b}}$ El Mostapha Rakib, ${ }^{\mathrm{c}}$ José A. S. Cavaleiro, $^{\mathrm{b}}$ Sergei M. Dolotov, ${ }^{\mathrm{a}}$ \\ Ivan V. Ivanov, ${ }^{a}$ Dmitrii A. Cheptsov, ${ }^{a}$ and M. Graça P. M. S. Neves ${ }^{b}$ \\ a'D.I. Mendeleev University of Chemical Technology of Russia, 125047 Moscow, Russian Federation \\ ${ }^{\mathrm{b}}$ QOPNA and LAQV-REQUIMTE, Department of Chemistry, University of Aveiro, 3810-193 Aveiro, Portugal \\ 'Laboratory of Organic and Analytic Chemistry, Faculty of Sciences and Technics, Sultan Moulay Slimane University BP \\ 523, 2300 Beni-Mellal, Morocco \\ ${ }^{\circledR 1}$ Corresponding author E-mail: valerii.traven@gmail.com \\ ${ }^{@ 2}$ Corresponding author E-mail:_nmoura@ua.pt
}

\begin{abstract}
The interaction of free-bases and $\mathrm{Zn}$ (II) complexes of meso-tetraphenylporphyrin, and its $\beta$-functionalized derivatives with photogenerators of acidity (PGAs, hexachloroethane or tribromoethanol) has been studied in toluene and also embedded in polymer films. The free-bases undergo fast reversible protonation during the irradiation procedure. The photoprotonation of free-bases by PGAs is accompanied by the fluorescence decay of each porphyrin substrate. The relative rates of such photoprotonation of free-base porphyrins depend to a certain extent on the porphyrin structure. The similar protonation and the fluorescence decay of the meso-tetraphenylporphyrin derivatives in the presence of PGAs also take place in a polymer film. The related Zn(II) complexes undergo photolysis under the conditions used with the fluorescence decay as well. The protonation and sharp fluorescence decay of meso-tetraphenylporphyrin derivatives during their irradiation can find application in photosensory technologies, information optical recording and antibacterial phototherapy.
\end{abstract}

Keywords: Tetraphenylporphyrin derivatives, photogenerators of acidity, protonation, fluorescence decay.

\section{Протонирование мезо-тетрафенилпорфирина и его $\beta$-производных фотогенераторами кислотности в толуоле и в полимерной пленке}

\author{
В. Ф. Травень, ${ }^{a} @ 1$ Н. М. М. Моура, ${ }^{\mathrm{b} @ 2}$ С. Б. Скачкова, ${ }^{\mathrm{a}}$ М. А. Ф. Фаустино, ${ }^{\mathrm{b}}$ \\ Э. М. Ракиб, ${ }^{\text {c } А ж . ~ А . ~ С . ~ К а в а л е и ̆ р о, ~}{ }^{\mathrm{b}}$ С. М. Аолотов, ${ }^{a}$ И. В. Иванов, ${ }^{a}$ А. А. Чепцов, ${ }^{a}$ \\ М. Г. Р. М. С. Невес
}

\footnotetext{
аРоссийский химико-технологический университет им. Д.И. Менделеева, 125047 Москва, Россия ${ }^{\mathrm{b}}$ QOPNA и LAQV-REQUIMTE, Кафедра химии, Университет Авейру, 3810-193 Авейру, Португалия сЛаборатория органической и аналитической химии, Факультет науки и техники университета султана Мулай Слимана ВР 523, 2300 Бени-Меллаль, Марокко

${ }^{\circledR 1}$ E-mail: valerii.traven@gmail.com

@2E-mail:_nmoura@ua.pt
}

Изучено взаимодействие мезо-тетрафенилпорфирина, его $\beta$-функционализированных производных и их Zn(II)комплексов с фотогенераторами кислот (ФГК, гексахлорэтан или трибромэтанол) в толуоле и в полимерных пленках. Свободнье основания подвергаются при этом быстрому и обратимому протонированию. Относи- 
тельные скорости фотопротонирования в определенной степени зависят от структуры порфирина. Фотопротонирование порфиринов сопровождается исчезновением их флуоресценции. Аналогичные протонирование и исчезновение флуоресценции производных мезо-тетрафенилпорфирина в присутствии ФГК происходят и в полимерной пленке. Zn(II)-Комплексы указанных порфиринов в названных условиях подвергаются фотолизу. Протонирование с потерей флуоресценциии производных мезо-тетрафенилпорфирина при их облучении может найти применение в фотосенсорных технологиях, системах оптической записи информации и антибактериальной фотодинамической терапии.

Ключевые слова: Производные тетрафенилпорфирина, фотогенераторы кислот, протонирование, затухание флуоресценции.

\section{Introduction}

Porphyrins and related macrocycles play not only significant roles in vital biological processes (e.g., respiration, photosynthesis, electron transportation and others), but also are being recognized as important partners in a wide range of applications..$^{[1,2]}$ The natural macrocycles and their synthetic analogues demonstrate photophysical and photochemical features for being used as possible components of molecular electronics and photonics devices, ${ }^{[3,4]}$ in photovoltaic solar cells like dye-sensitized solar cells (DSSC) ${ }^{[5-10]}$ and in medicine. The medicinal significance of porphyrin derivatives is due to their optical features (such as the strong light absorption and fluorescence) and so such compounds have been successfully used as photosensitizers in different contexts of photodynamic therapy (PDT) of cancer and also in image-guided theranostic processes. ${ }^{[11-14]}$ It might be possible that new but still unknown potential applications can become available with further studies. Therefore, the behavior of a porphyrin and derivatives in various processes initiated by irradiation, simply in solvent or embedded in polymer films is of great interest. ${ }^{[15-17]}$

We have previously shown that the irradiation of some organic substrates in the presence of polychloroalkanes is accompanied by the generation of acidity that led to the corresponding acid-catalyzed reactions or to sensory effects ${ }^{[18]}$ Moreover, photodehydrogenation of aryl(hetaryl) pyrazolines in the presence of carbon tetrachloride or hexachloroethane has been successfully used for optical information recording. ${ }^{[19-21]}$

Under such context, we decided to evaluate the behavior of porphyrin macrocycles, in the presence of acid photogenerators in toluene or embedded in polymer films. The compounds used were of meso-tetraphenylporphyrin
TPP (1-H), its Zn(II)-complex (1-Zn) and derivatives 2 and $\mathbf{3}$. These derivatives containing respectively a formyl and an aryl(pyrazolinyl) groups as substituents at $\beta$-pyrrolic position in each case (Figure 1), could influence the expected protonation procedure. Hexachloroethane (HCE) and tribromoethanol (TBE) have been selected as the PAGs.

It has been earlier reported that the UV light irradiation of TPP in chlorinated solvents in the presence of silica leads to the TPP protonated form. The process has been explained by the photochemical decomposition of the solvent

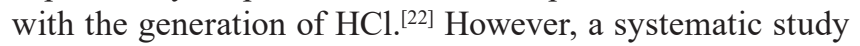
of the interaction of meso-tetraphenylporphyrin and of its $\beta$-functionalized derivatives with photogenerators of acid in toluene and in polymer film, as far as we know, has not been reported before.

\section{Experimental}

The free base meso-tetraphenylporphyrin $(\mathbf{1}-\mathbf{H}),{ }^{[23-25]}$ their $\mathrm{Zn}(\mathrm{II})$ complex $(\mathbf{1 - Z n})^{[26]}$ and the 2-formyl-meso-tetraphenylporphyrin $2^{[27]}$ were prepared following well-established protocols reported in literature. The porphyrin-pyrazoline hybrids (3a-d-H and $\mathbf{3 a - d}-\mathbf{Z n}$ ) were prepared by reaction of the free base 2-vinyl5,10,15,20-tetraphenylporphyrin or its $\mathrm{Zn}$ (II) complexes with the appropriate nitrile imine, generated in situ from the adequate ethyl hydrazono- $\alpha$-bromoglyoxylate as previously reported. ${ }^{[28]}$ The structures of all the synthesized derivatives were confirmed by ${ }^{1} \mathrm{H}$ NMR and mass spectrometry techniques. The experimental data are in agreement with the ones described in literature. The other chemicals were supplied by Sigma-Aldrich as HPLC or spectral grade and were used without further purification.

Electronic absorption spectra were recorded on an APELPD_303UV spectrometer and fluorescent spectra - on Cary Eclipse (Varian) spectrofluorimeter. The band of excitation was $420 \mathrm{~nm}$.
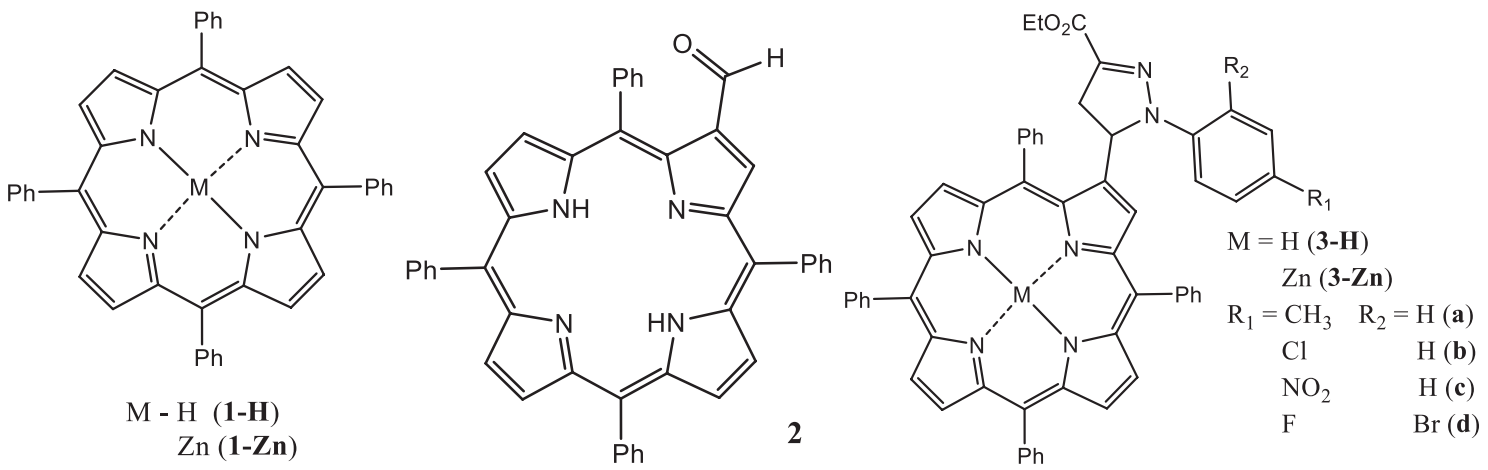

Figure 1. Structures of the studied compounds: meso-tetraphenylporphyrin 1-H, 1-Zn and the $\beta$-functionalized derivatives $\mathbf{2}$ and $\mathbf{3 a - d .}$ 

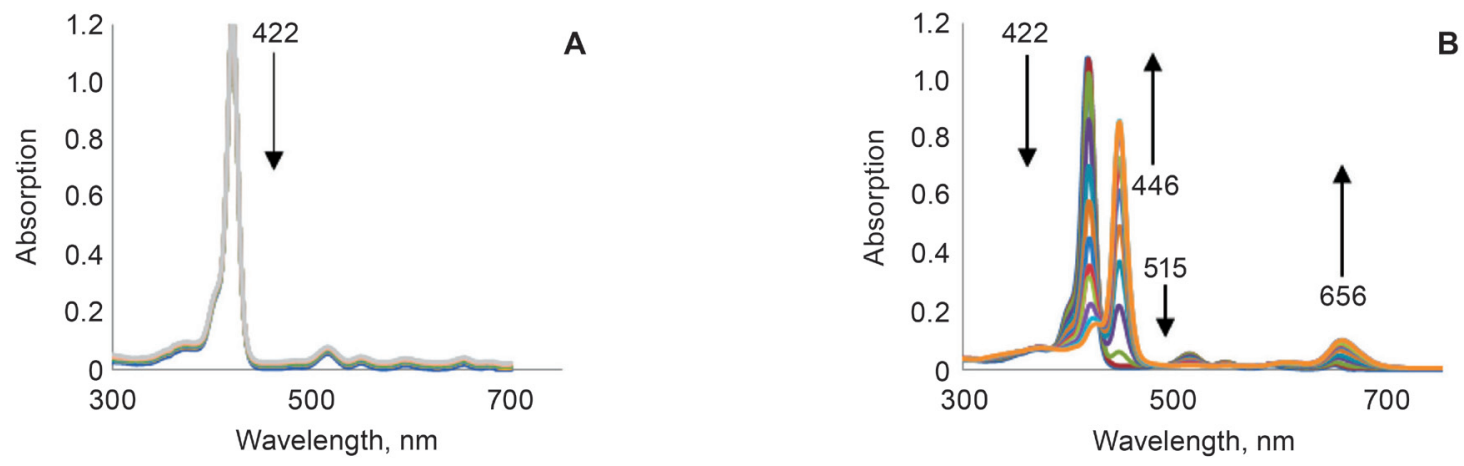

Figure 2. A) Changes of the absorption spectra of 1-H during irradiation in toluene; B) Changes of the absorption spectra of 1-H during irradiation in toluene with addition of HCE.

The photo-irradiations were carried out using an L 5283 xenon lamp (HAMAMATZU lamp) through the light filter A-03 to select a light in the region at $240-400 \mathrm{~nm}$. Rate constants of photoprotonation reactions were found by graphics method with use of linear form of the first order reaction. Changes of optical densities of the porphyrin have been used in the region of $0.2-0.8$ for the rate constants calculations. The average rate constants given in Table 1 are obtained from four convergent results with accuracy $5 \%$.

Polymer films were fabricated using the pouring method. A solution containing copolymer methylmethacrylate-ethylacrylate, and porphyrins $\mathbf{1 - H}$ or $\mathbf{1 - Z n}$ as well as hexachloroethane, in a mixture dichloroethane-methylene chloride (1:4) was poured onto a horizontally placed Petri dish, afterwards the solvent was evaporated. The film (thickness around $80-100 \mu \mathrm{m}$ ) was then removed from the dish before undergoing irradiation.

\section{Results}

\section{Interaction of meso-Tetraphenylporphyrin $\mathbf{1 - H}$} with PGAs in Toluene

The irradiation of porphyrin $\mathbf{1 - H}$ in the region of 240-400 nm without addition of any PGA does not lead to noticeable changes in the absorption spectra (Figure 2A). However, a slight decrease of the Soret band intensity can be mentioned. At the exposure time equal to $180 \mathrm{~s}$ the conversion of the 1-H turns to be not more than $0.3 \%$ (see Table 1 for more detail).

The addition of hexachloroethane to the solutions of $\mathbf{1 - H}$ in toluene (with concentration equal to $3.9 \cdot 10^{-2} \mathrm{M}$ ) leads to the fast and definite changes in the absorption spectra of the substrate. The intense Soret band at $422 \mathrm{~nm}$ is decreased during the irradiation, while the new band at $446 \mathrm{~nm}$ of high intensity and the band at $656 \mathrm{~nm}$ of low intensity are proportionally increased (Figure 2B). These changes correspond to the protonation of the porphyrin core. After the exposure time equal to $8 \mathrm{~s}$, the protonation of $\mathbf{1 - H}$ has been found to reach $88 \%$. Irradiation of the porphyrin $\mathbf{1 - H}$ in the presence of 2,2,2-tribromoethanol in toluene (with concentration equal to $1.8 \cdot 10^{-2} \mathrm{M}$ ) provides similar spectral changes, but the rate of protonation is higher. After the exposure time equal to $0.5 \mathrm{~s}$, the protonation of $\mathbf{1 - H}$ has been found to reach $84 \%$ (Figure S1).
The photoinduced protonation of $\mathbf{1 - H}$ by both HCE and TBE is a reversible process as the thermal protonation is. Addition of triethylamine at the final step of irradiation recovers the initial absorption spectra of the porphyrin freebase 1-H. Similar changes in its absorption spectra have been recorded after addition of $p$-toluenesulphonic acid to solutions of porphyrin $\mathbf{1 - H}$ in toluene.

The irradiation of the porphyrin $\mathbf{1 - H}$ in the presence of PGAs leads to the fluorescence decay. For example, irradiation of the 1-H in toluene in the presence of 2,2,2-tribromoethanol leads to a decrease in the intensity of the fluorescence maximum at $656 \mathrm{~nm}$ and low-intensity maximum at $720 \mathrm{~nm}$. Almost complete disappearance of the fluorescent signals has been observed during irradiation for several seconds (Figure 3).

\section{Interaction of Porphyrin 2 with HCE in Toluene}

The interaction of the PAGs with the meso-tetraphenylporphyrins bearing additional substituent at the $\beta$-pyrrolic position were also performed in toluene. The absorption spectra of porphyrin $\mathbf{2}$ with a $\beta$-located formyl group during the irradiation without any additive are shown in Figure 4A. When compared with porphyrin $\mathbf{1 - H}$, one can see the compound 2 to be much less stable during irradiation reaching a conversion of $60 \%$ after an irradiation time of $300 \mathrm{~s}$.

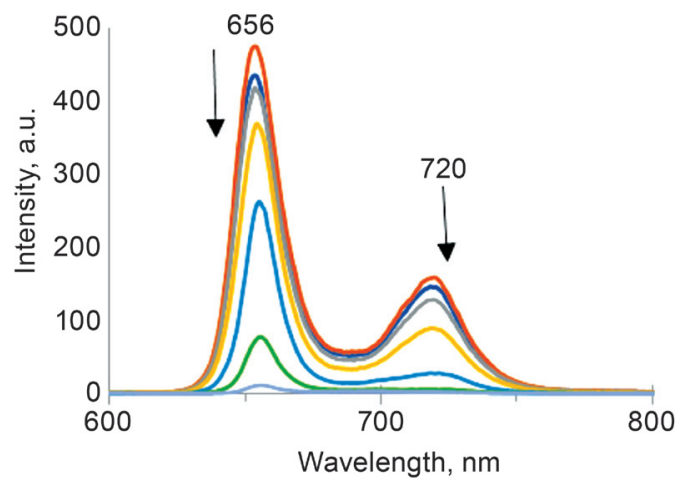

Figure 3. Changes in the fluorescence spectra of 1-H during irradiation in toluene with the addition of 2,2,2-tribromoethanol. 

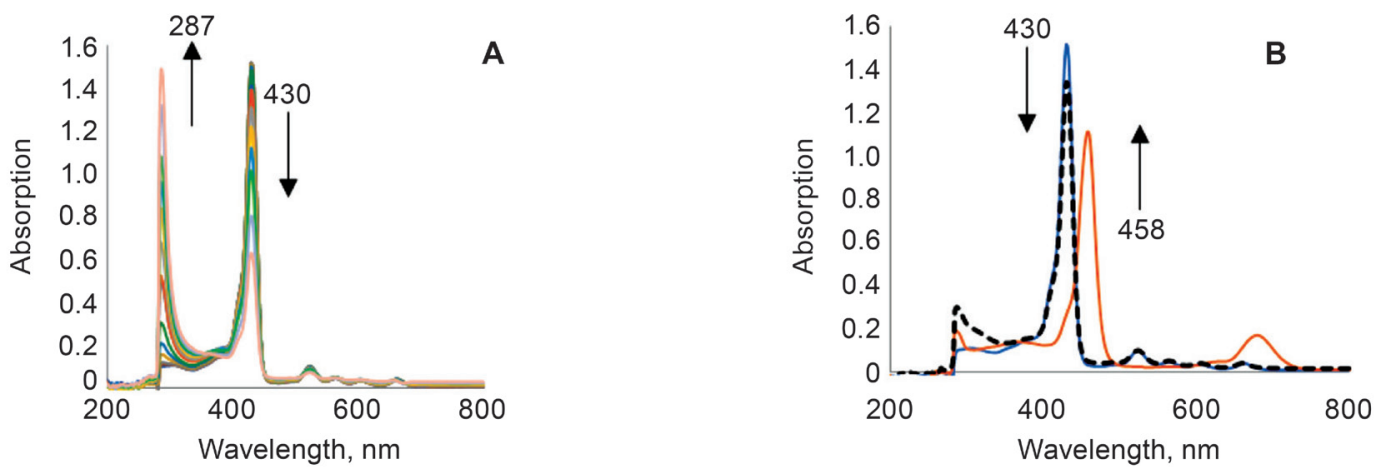

Figure 4. A) Changes in the absorption spectra of porphyrin 2 during irradiation in toluene without any PGA; B) Absorption spectra of the porphyrin 2 during its irradiation in toluene with addition of hexachloroethane for $3 \mathrm{~s}$ (dotted line - absorption spectrum after triethylamine addition at the end of irradiation).

Nevertheless, irradiation of the porphyrin 2 in toluene in the presence of hexachloroethane leads to fast protonation (3 s) of the porphyrin derivative. As with $\mathbf{1 - H}$ protonation of $\mathbf{2}$ by PGA is a reversible process affording after the addition of triethylamine at the final step of irradiation the absorption spectrum of the free-base 2 (Figure 4B, green dotted line).

\section{Interaction of Porphyrins $\mathbf{3 a - d - H}$ with PGAs in Toluene}

The insertion of an (aryl)pyrazolinyl fragment at the $\beta$-pyrrolic position of the porphyrin core leads to certain changes in the photosensitive behavior of the macrocycle. After the irradiation time equal to $300 \mathrm{~s}$ conversion of the 3a-H at the same time does not exceed $25 \%$ (Figure $5 \mathrm{~A})$.

The addition of hexachloroethane to $\mathbf{3 a - H}$ leads to a strong increase of transformation. Irradiation of the $\mathbf{3 a}-\mathbf{H}$ in the presence of $\mathrm{HCE}$ provides reversible protonation of the porphyrin moiety. Addition of triethylamine at the final step recovers the initial absorption spectrum of the $\mathbf{3 a - H}$ (Figure 5B). Looking at the changes in the absorption spectra, internal NH functions of porphyrin $\mathbf{3 a - H}$ can be sug- gested as place of protonation. The presence of 2,2,2-tribromoethanol leads to a large increase in the photoprotonation rate of the porphyrin 3-H. For example, the exposure time up to the same conversion (around $90 \%$ ) turned to be equal $0.5 \mathrm{~s}$ for the $\mathbf{3 a - H}$.

The behavior of the other pyrazolinylporphyrins, $\mathbf{3 b}-\mathbf{H}, \mathbf{3 c}-\mathbf{H}$ and $\mathbf{3 d}-\mathbf{H}$ after being irradiated in the presence of PGAs follows the profile discussed for 3a-H (see Supplementary Data).

\section{Interaction of Porphyrin $\mathbf{1 - H}$ with Photogenerators of Acidity in a Polymer Film}

Since many photoinduced transformations of fluorescent substrates turn to have potential in sensing materials applications, we have evaluated possibility of protonation of tetraphenylporphyrin $\mathbf{1 - H}$ by acid photogenerators after being incorporated in a film based in copolymer MMA-EA (methylmetacrylate-ethylacrylate). The changes of the absorption spectra of these porphyrins during their irradiation (for $120 \mathrm{~s}$ ) in the polymer film containing tribromoethanol are shown in Figure 6A.

As it was observed in the assays performed in toluene, the protonation of porphyrin $\mathbf{1 - H}$ in the presence of PGA
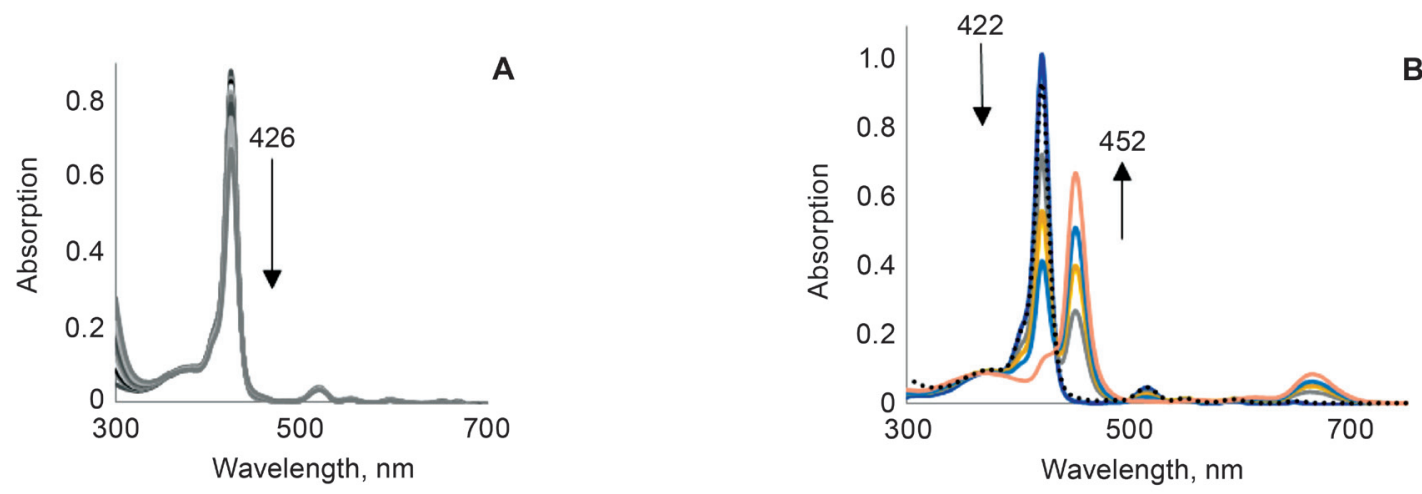

Figure 5. A) Changes in the absorption spectra of $\mathbf{3 a - H}$ in toluene during irradiation; B) Changes in the absorption spectra of the porphyrins 3a-H during irradiation in toluene in the presence of HCE (dotted line - absorption spectrum after triethylamine addition at the end of irradiation). 

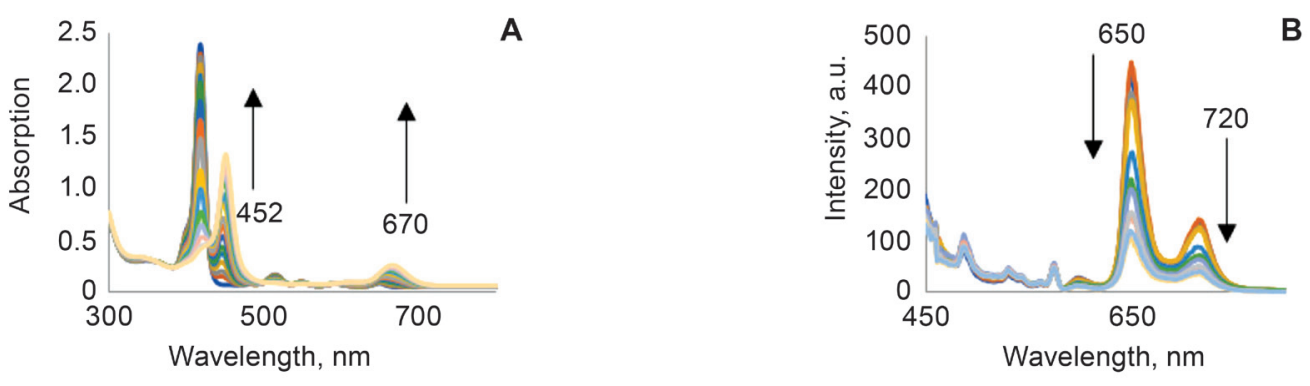

Figure 6. A) Changes in the absorption spectra of the porphyrin 1-H during irradiation with tribromoethanol in copolymer MMA-EA; B) Emission spectra of 1-H during irradiation with tribromoethanol in copolymer MMA-EA.

takes also place after being supported of both compounds in the polymer film but obviously with lower rates. The protonation is also accompanied by a significant fluorescence decay as it is patent in Figure 6B.

\section{Transformations of Zn(II) Complexes of meso- Tetraphenylporphyrin and its $\beta$-Functionalized Derivatives in the Presence of Photogenerators of Acidity}

The behavior of $\mathrm{Zn}$-complexes of the related porphyrins 1-3 during their irradiation in the presence of PGAs turns to be much different. First of all, it should be mentioned that these $\mathrm{Zn}$-complexes are much less stable at the irradiation (Figure 7A). For instance, the 1-Zn derivative photodegradates by $33 \%$ after $240 \mathrm{~s}$ of UV-light irradiation in the absence of any PGAs. No protonation can be seen during irradiation of $\mathbf{1 - Z \mathbf { n }}$ in the presence of $\mathrm{HCE}$, since addition of triethylamine after irradiation does not recover spectrum of the starting substrate (Figure 7B). However, effect of PGAs on the photolysis of $\mathbf{1 - Z n}$ is obvious. It undergoes much faster in the presence of HCE (see Table 2 for more detail).

The photolysis of $\mathbf{1 - Z n}$ undergoes even faster in the presence of TBE. $\beta$-Functionalization of $\mathrm{Zn}$-complexes increases also the rate of their photolysis. Changes of the absorption spectra of $\mathbf{3 a - Z n}$ in toluene during irradiation without any additive and in the presence of HCE are compared in Figures $8 \mathrm{~A}$ and $8 \mathrm{~B}$, respectively (see also Table 2 for more detail).
Either in toluene solution or when embedded in the polymer film, the fluorescence of $\mathrm{Zn}$ (II)-complexes decreased during irradiation in the presence of PGAs. As example, changes of emission spectra during irradiation of $\mathbf{1 - Z n}$ with tribromoethanol in toluene and in polymer film are compared in Figures 9A and 9B, respectively.

\section{Discussion}

The studied transformations of meso-tetraphenylporphyrin and its derivatives during their irradiation in the presence of hexachloroethane or tribromoethanol lead to the protonation of the porphyrin substrate. As it is well known, porphyrins (P) are amphoteric, presenting acidic and basic properties due to the inner pyrrolic nitrogens. In the presence of a strong base, the inner protons are removed affording the anionic species, while in acidic conditions the nitrogens of imine type are able to accept extra protons affording monocation (MP) and dication (DP) species. ${ }^{[29-31]}$ Monoprotonated porphyrins are known to be a highly unstable cations and in some cases seem to be difficult for detection. Accordingly to Rudine et al., ${ }^{[31]}$ the absorption bands at $448 \mathrm{~nm}$ and the $660 \mathrm{~nm}$ recorded in this study relate to the DP form of meso-tetraphenylporphyrin (Figure 2B).

We have compared the relative rates of protonation of meso-tetraphenylporphyrin $\mathbf{1 - H}$ and its derivatives during irradiation in the presence of hexachloroethane. The comparison data are given in the Table 1. Even though, the free bases of porphyrins 1-3 undergo a photolysis in some extent
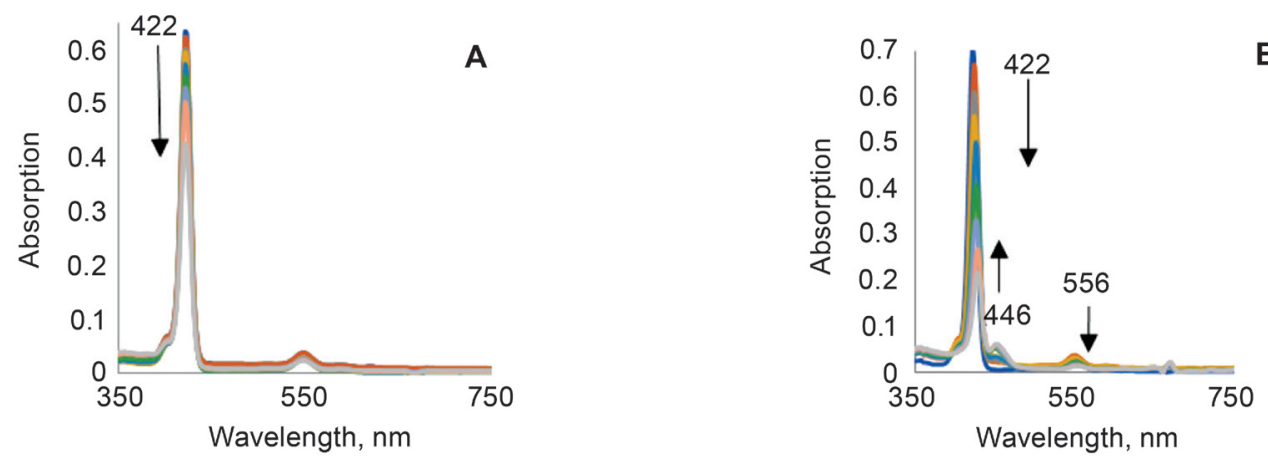

Figure 7. A) Changes in the absorption spectra of the porphyrin 1-Zn during irradiation; B) Changes in the absorption spectra of the porphyrin $\mathbf{1 - Z n}$ during irradiation in the presence of HCE. 

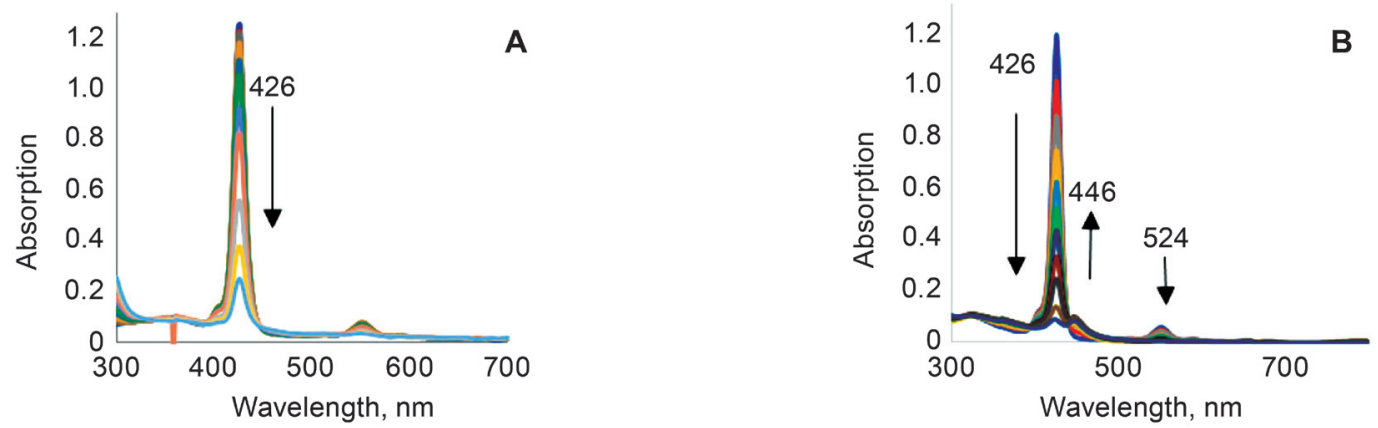

Figure 8. A) Changes of the absorption spectra of $\mathbf{3 a}-\mathbf{Z n}$ in toluene during irradiation; B) in the presence of HCE

Table 1. Relative rates of photolysis of the porphyrins 1-3 and their protonation in the presence of hexachloroethane (irradiation by L 5283 xenon lamp at $240-400 \mathrm{~nm}$ ).

\begin{tabular}{ccccc}
\hline \multirow{2}{*}{ Porphyrin } & $\lambda_{\max }, \mathrm{nm}$ & $\varepsilon, \mathrm{mol}^{-1} \cdot \mathrm{cm}^{-1}$ & \multicolumn{2}{c}{$k, \mathrm{~s}^{-1}$} \\
\cline { 4 - 5 } & 420 & 75700 & 0.000106 & 0.303 \\
$\mathbf{1}-\mathbf{H}$ & 432 & 69200 & 0.00021 & 0.22 \\
$\mathbf{3} \mathbf{a}-\mathbf{H}$ & 426 & 115500 & 0.000364 & 0.192 \\
$\mathbf{3 b}-\mathbf{H}$ & 428 & 81200 & 0.00025 & 0.552 \\
$\mathbf{3}-\mathbf{H}$ & 426 & 120000 & 0.000333 & 0.142 \\
3d-H & 428 & 111500 & 0.000334 & 0.262 \\
\hline
\end{tabular}

Table 2. Relative rates of photolysis of the Zn-complexes of porphyrins 1-3a-d and their phototransformation in the presence of hexachloroethane (irradiation by L 5283 xenon lamp at $240-400 \mathrm{~nm}$ ).

\begin{tabular}{ccccc}
\hline \multirow{2}{*}{ Porphyrin } & $\lambda_{\max }, \mathrm{nm}$ & $\varepsilon, \mathrm{mol}^{-1} \cdot \mathrm{cm}^{-1}$ & Without any PGA & With HCE \\
\cline { 4 - 5 } & 422 & 58300 & 0.00168 & 0.180 \\
1-Zn & 424 & 74200 & 0.00275 & 0.101 \\
3a-Zn & 428 & 98800 & 0.00189 & 0.128 \\
3c-Zn & 422 & 110200 & 0.00183 & 0.131 \\
3d-Zn & 422 & 120950 & 0.00115 & 0.0709 \\
\hline
\end{tabular}
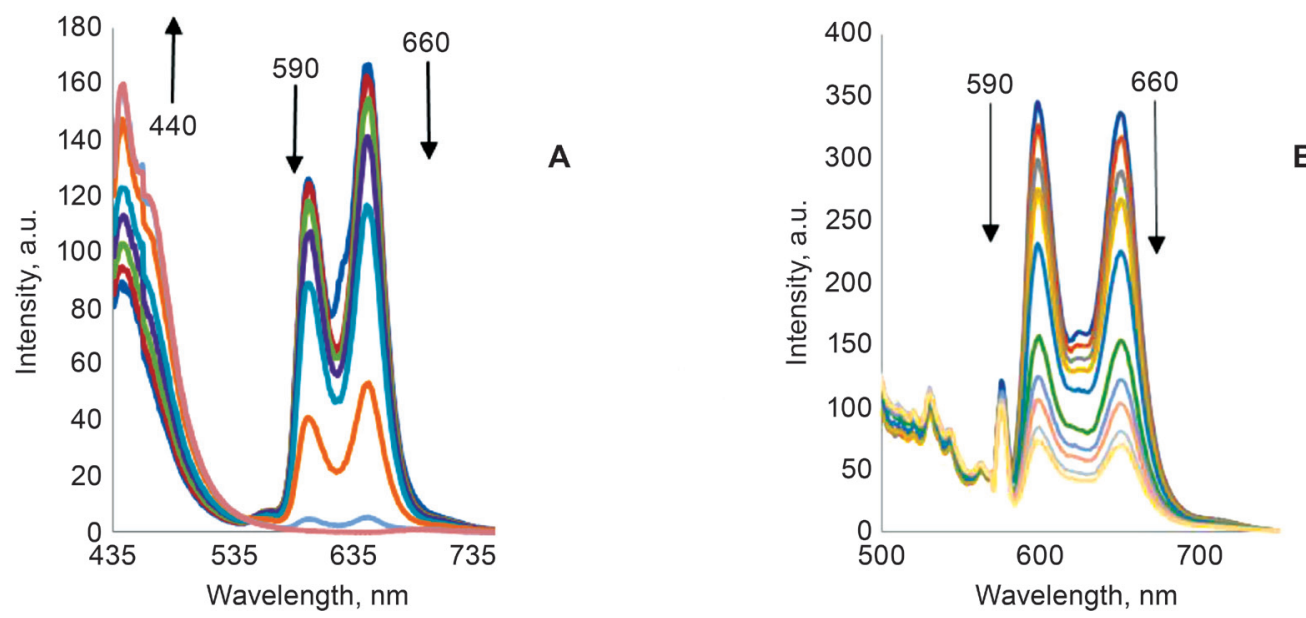

Figure 9. A) Changes of emission spectra during irradiation of $\mathbf{1 - Z n}$ with tribromoethanol in toluene (exposure time is $0.8 \mathrm{~s}$ ); B) Changes of emission spectra during irradiation of $\mathbf{1 - Z n}$ with tribromoethanol in copolymer MMA-EA (exposure time is $30 \mathrm{~s}$ ). 
under the used irradiation, their protonation by PGAs takes place much faster than their photolysis. In the case of mesotetraphenylporphyrin $\mathbf{1 - H}$ the rate ratio is up to $2.8 \cdot 10^{3}$ times. Another important point: the protonation of all the free base porphyrins 1-3 by PGAs is a reversible process. Moreover, the formed protonated forms of porphyrins 1-3 are thermally stable. They are not decomposed when the irradiation is over.

Protonation rates of $\mathrm{H}$-porphyrins $\mathbf{1 - 3}$ in the presence of $\mathrm{HCE}$ are not systematically depended on the porphyrin structure. All $\beta$-functionalized derivatives of meso-tetraphenylporphyrin are protonated some slower than $\mathbf{1 - H}$ itself. However, the compound $\mathbf{3 b}$ is protonated even faster when compared with $\mathbf{1 - H}$.

The fluorescence decay that follows photoprotonation of porphyrins 1-3 by PGAs both in toluene and in polymer film should be also commented, having in mind the earlier reported results. Rudine et al. did not report about fluorescence changes during total thermal protonation of the $\mathbf{T P P}^{[31]}$ Moreover, the red-shift in the emission spectra has been earlier reported. While studying the protonation of mesotetraphenylporphyrin TPP, De Luca et al. noticed that the fluorescence spectrum of the initial neutral form exhibits a typical two-banded feature which undergoes a definite redshift after protonation. ${ }^{[29]}$ However, the loss of fluorescence during interaction of porphyrins with PGAs is not much surprising. First of all, the addition of a proton to the imine fragment of porphyrin leads to a violation of the flatness of its molecule. The obvious repulsion of four hydrogen atoms in the DP macrocyclic core leads to substantial tilting of the pyrrole rings, in such a way that the pairs of two opposite nitrogen atoms turn to be located at opposite sides of the macrocycle plane. Moreover, it has been earlier shown that the DP molecules can associate with counter ions (e.g., halide ions) or neutral nucleophiles (e.g., water). The fluorescence quenching in the DP. $2 \mathrm{~A}^{-*}$ complexes with halides was proposed recently to be useful for the design of porphyrin molecular sensors for halides. ${ }^{[30]}$

As one can see, $\mathrm{Zn}$ (II) complexes of meso-tetraphenylporphyrin, and those of $\beta$-functionalized derivatives turned to be much less stable under the irradiation conditions selected and undergo the photolysis instead of protonation (Table 2). Moreover, in the presence of PGAs their photolysis undergoes certainly faster: for the $\mathbf{1 - Z n}$ the ratio of rate constants is more than 100 .

As in the case of metal-free porphyrins, photolysis of $\mathrm{Zn}(\mathrm{II})$ complexes in the presence of PGAs undergoes also with a sharp fluorescence decrease both in toluene and in polymer film.

\section{Conclusions}

meso-Tetraphenylporphyrin and its derivatives that contain a beta-formyl or aryl(pyrazolinyl) group as substituent undergo fast protonation when they are irradiated in the presence of photogenerators of acidity (hexachloroethane or tribromoethanol). The photoprotonation is reversible and undergoes much faster than photolysis as a sub-side transformation. In opposite to thermal process, photoprotonation by PGAs leads to fluorescence decay of the porphyrin substrate. Photoprotonation of tetraphenylporphyrin and its derivatives by PGAs that followed by the fluorescence decay undergoes also in the polymer film. The total fluorescence decay of the porphyrins 1-3a-d during their irradiation in the presence of PGAs in polymer films can find application in photosensory technologies. It can also be useful in the design of novel media for optical information recording, since one of the trends there is the use of substrates that possess sharp fluorescence change under irradiation. ${ }^{[32,33]}$ In addition, results of this study are of interest for biochemical applications, since protonated forms of porphyrins are widely studied in antibacterial photodynamic therapy. ${ }^{[34-36]}$

Acknowledgments. This work was funded by the Russian Science Foundation, grant no. 17-13-01302. The authors are grateful to University of Aveiro and FCT/MCT for the financial support for QOPNA research Unit (FCT UID/ QUI/00062/2019, through national funds and, where applicable, co-financed by the FEDER, within the PT2020 Partnership Agreement), and to the Portuguese NMR Network. The research contracts of NMM Moura (REF.-048-88$\mathrm{ARH} / 2018)$ is funded by national funds (OE), through FCT.

\section{References}

1. Amanullah S., Singha A., Dey A. Coord. Chem. Rev. 2019, 386, 183-208.

2. Harmatys K.M., Overchuk M., Zheng G. Acc. Chem. Res. 2019, 52, 1265-1274.

3. Kadish K.M., Smith K.M., Guilard R. Handbook of Porphyrin Science, Vols. 10-12, Singapore: World Scientific Publishing Company Co, 2010.

4. Mukhopadhyay R.D., Kim Y., Koo J., Kim K. Acc. Chem. Res. 2018, 51, 2730-2738.

5. Di C.G., Biroli O.A., Pizzotti M., Tessore F. Front. Chem. 2019, 7, 177.

6. Urbani M., de la Torre G., Nazeeruddin M.K., Torres T. Chem. Soc. Rev. 2019, 48, 2738-2766.

7. Lu J., Liu S., Wang M. Front. Chem. 2018, 6, 541.

8. Mahmood A., Hu J.-Y., Xiao B., Tang A., Wang X., Zhou E. J. Mater. Chem. A 2018, 6, 16769-16797.

9. Ji J.-M., Zhou H., Kim H.K. J. Mater. Chem. A 2018, 6, 14518-14545.

10. Kumar D., Wong K.-T. Mater. Today Energy 2017, 5, 243-279.

11. Giuntini F., Boyle R., Sibrian-Vazquez M., Vicente M.G.H., Graca H.M. Porphyrin Conjugates for Cancer Therapy. In: Handbook of Porphyrin Science, Vol. 27 (Kadish K.M., Smith K.M., Guilard R., Eds.), Singapore: World Scientific Publishing Company Co, 2010. p. 303-416.

12. Rajora M.A., Lou J.W.H., Zheng G. Chem. Soc. Rev. 2017, 46, 6433-6469.

13. Bolze F., Jenni S., Sour A., Heitz V. Chem. Commun. 2017, 53 , 12857-12877.

14. Singh S., Aggarwal A., Bhupathiraju N.V.S.D.K., Arianna G., Tiwari K., Drain C.M. Chem. Rev. 2015, 115, 10261-10306.

15. Mesquita M.Q., Dias C.J., Neves M.G.P.M.S., Almeida A., Faustino M.A.F. Molecules 2018, 23, 2424.

16. Mesquita M.Q., Dias C.J., Gamelas S., Fardilha M., Neves M.G.P.M.S., Almeida A., Faustino M.A.F. An. Acad. Bras. Ciênc. 2018, 90, 1101-1130.

17. Castro K.A.D.F., Moura N.M.M., Simões M.M.Q., Cavaleiro J.A.S., Faustino M.D.A.F., Cunha Â, Paz F.A.A., Mendes R.F., Almeida A., Freire C.S.R., Vilela C., Silvestre A.J.D., Nakagaki S., Neves M.D.G.P.M.S. Appl. Mater. Today 2019, 19, 332-341. 
18. Traven V.F., Cheptsov D.A., Bulanova M.V., Solovjova N.P., Chibisova T.A., Dolotov S.M., Ivanov I.V. Photochem. Photobiol. 2018, 94, 659-666.

19. Pohlers G., Scaiano J.C., Sinta R., Brainard R., Pai D. Chem. Mater. 1997, 9, 1353-1361.

20. Traven V.F., Cheptsov D.A., Vershinina G.V., Solovjeva N.P., Chibisova T.A., Dolotov S.M., Ivanov I.V. J. Photochem. Photobiol. A: Chemistry 2018, 351, 8-15.

21. Traven V.F., Dolotov S.M., Ivanov I.V., Barachevsky V.A., Kobeleva O.I., Valova T.M., Platonova I.V., Ajt A.O. RU Patent 2478116 Russia, 2013.

22. Scolaro M.L., Romeo A., Castriciano A.M., De Luca G., Patane S. J. Am. Chem. Soc. 2003, 125, 2040-2041.

23. Adler A.D., Longo F.R., Shergalis W. J. Am. Chem. Soc. 1964, $86,3145-3149$.

24. Adler A.D., Longo F.R., Finarelli J.D., Goldmacher J., Assour J., Korsakoff L. J. Org. Chem. 1967, 32, 476.

25. Gonsalves A.M.d.A.R., Varejão J.M.T.B., Pereira M.M. J. Heterocycl. Chem. 1991, 28, 635-640.

26. Buchler J.W. In: Porphyrins and Metalloporphyrins, Ch. 5 (Smith K.M., Ed.), Amsterdam: Elsevier, 1975. pp. 157-231.

27. Moura N.M.M., Faustino M.A.F., Neves M.G.P.M.S., Duarte A.C., Cavaleiro J.A.S. J. Porphyrins Phthalocyanines 2011, $15,652-658$.
28. Moura N.M.M., Faustino M.A.F., Neves M.G.P.M.S., Tomé A.C., Rakib E.M., Hannioui A., Mojahidi S., Hackbarth S., Röder B., Paz F.A.A., Silva A.M.S., Cavaleiro J.A.S. Tetrahedron 2012, 68, 8181-8193.

29. De Luca G., Romeo A., Scolaro L.M., Ricciardi G., Rosa A. Inorg. Chem. 2007, 46, 5979-5988.

30. Kruk M.M., Starukhin A.S., Maes W. Macroheterocycles 2011, 4, 69-79.

31. Rudine A.B., DelFatti B.D., Wamser C.C. J. Org. Chem. 2013, $78,6040-6049$.

32. Dvornikov A.S., Zhang H., Rentzepis P.M. J. Photochem. Photobiol. A: Chemistry 2009, 201, 57-61.

33. Barachevskiy V., Krayushkin M., Kiyko V. Light-Sensitive Organic Recording Media for Three-Dimensional Optical Memory. In: Photon-Working Switches (Yokoyama Y., Nakatani K., Eds.), Japan: Springer Japan KK, 2017. pp. 181-207.

34. Nitzan Y., Gutterman M., Malik Z., Ehrenberg B. Photochem. Photobiol. 1992, 55, 89-96.

35. Amos-Tautua B.M., Songca S.P., Oluwafemi O.S. Molecules 2019, 24, 2456-2084.

36. Castro K.A.D.F., Moura N.M.M., Figueira F., Ferreira R.I., Simões M.M.Q., Cavaleiro J.A.S., Faustino M.A.F., Silvestre A.J.D., Freire C.S.R., Tomé J.P.C., Nakagaki S., Almeida A., Neves M.G.P.M.S. Int. J. Mol. Sci. 2019, 20, 2522-2543.

Received 15.11.2019 Accepted 07.12.2019 